\title{
Ekslibris Sanatında Aquatinta Tekniği ile Tonlama
}

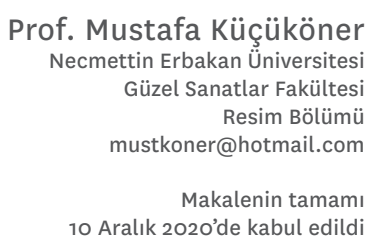

Özet

Genel olarak bir mülkiyet işareti olarak kullanılan Ekslibris, günümüzde bir sanatsal eser üretme yöntemi olarak da kullanılmaktadır. "Gerçek bir entelektüelin en değer verdiği taşınabilir mülkiyeti kitaptır. Kitapta genel bir uygulama olarak, ilk sayfaya ya da kapak içine kitabın sahibinin adı ve tarih yazılmaktadır.” (Kahramankaptan, 1997, s.67)

Ekslibris hem kitabın aidiyetini, kime veya hangi kuruma ait olduğunu temsil etmekte, hem de içinde bulunduğu kitaba ve adına yapılan kişiye ait tanıtımda bulunmaktadır. Bunlara ek olarak günümüzde serbest olarak da çalışılmaktadır. Özellikle günümüzde modern ve yeni tekniklerle de ekslibris yapılmaktadır. Bu tekniklerden biri de " $\mathrm{C}_{5}$ " kodu ile aquatinta tekniğidir. $\mathrm{Bu}$ çalışmamızda aquatinta tekniği kullanılarak yapılan ekslibrislerden örnek 200 eserler ele alınacak ve aquatinta tekniği ile resimde tonlama yapma ilişkisi değerlendirilecektir.

Anahtar Sözcükler: ekslibris, aquatinta, ton. 


\section{Ekslibris Nedir?}

“Ekslibris, kitapseverlerin kitaplarının iç kapağına yapıştırdıkları üzerinde adlarının ve değişik konularda resimlerin yer aldığı küçük boyutlu özgün yapıtlardır. Kitabın kartviziti ya da tapusudur. Kitap sahibini tanıtır, onu yüceltir ve kitabı ödünç alan kişiyi geri getirmesi konusunda uyarır." (Pektaş, 2017, s. 11) “Sözcük olarak “....’nın kitaplığından” veya “....’nın kütüphanesi ait” anlamına gelir.” (Pektaş, 2017, s.11).

Geçmişi Antik Mısır dönemine kadar giden ve Asur Devletinden Uzak Doğuya kadar farklı medeniyetlerde örneklerine rastlanan ekslibris, matbaanın bulunması ve kitapların çoğaltılmaya başlaması ve kitapların koruma ve tanıma dayalı ihtiyaçlarını karşılayan bir sanat dalına dönüşmüştür. Bu şekli ile ilk sanatsal örneklerini matbaanın kullanılmaya başladığı Almanya’da görülmektedir. Görsel 1'de Alman sanatçı Albrecht Dürer'in bir ekslibrisi görülmektedir.

Zaman içinde farklı tanıtım türlerinde kendini gösteren ekslibris sanatı, modern tekniklerde çok daha hızlı çoğaltılan kitaplarda da farklı şekillerde kullanılmıştır. Bu gelişmelerle birlikte 1850 yıllarında popüler olmaya başlayan koleksiyonerlik sayesinde başka sosyal alanlara taşınmaya başlamıştır. Farklı alanlara taşındıkça halk arasında bir iletişim aracı olmaya da başlamıştır. "Latinceden gelen, "Ex-libris olarak olarak yazılan ve ingilizce karşılığı "Bookplate” olan ekslibris önemli bir iletişim aracıdır." (Pektaş, 2017, s.11)

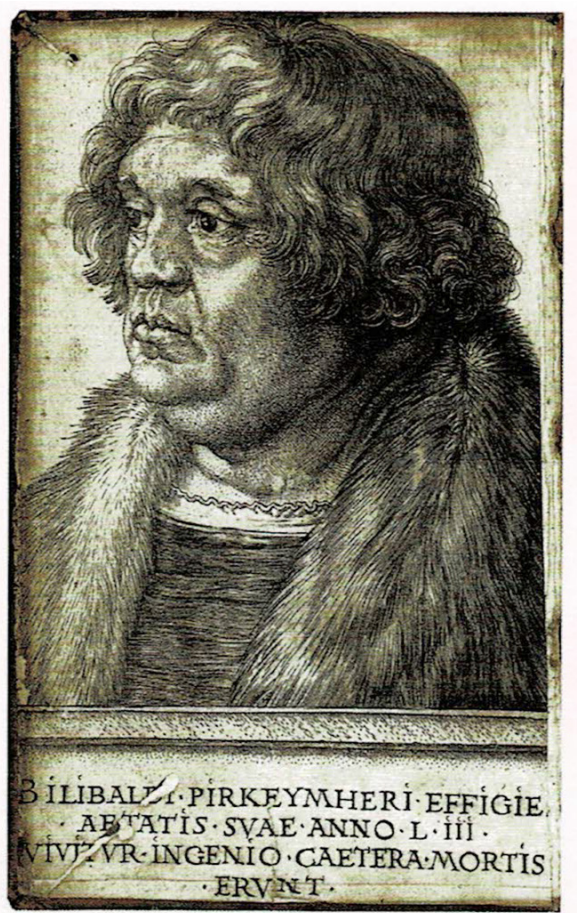

Görsel 1: Albrecht Dürer, Ekslibris Willibald Pirckheimer, 1524, C3, 181x100 mm.
20. yüzyılın başlarında farklı disiplinlerdeki sanatçılar da ekslibris yapmaya başlamış, kendi üsluplarında çalışmalar üretmişlerdir. Bu yüzyıl içinde özellikle Avrupa'da ekslibris dernekleri, vakıfları kurulmuş, kongreler, takaslar ve yarışmalar yapılmaya başlanmış, koleksiyonculuk ile beraber ekslibris müzeleri açılmaya başlanmıştır.

Matbaa temelli baskı tekniklerine 20.yüzyılda gelişen modern sanatsal baskı teknikleri de eklenmiş, özellikle gravür, serigrafi ve litografi teknikleri öne çıkmaya başlamıştır. 21.yüzyıla girerken bu tekniklere bilgisayar destekli tasarım teknikleri de eklenmeye başlamış, günümüzde hemen her teknikten ve özellikle yeni arayışlarda da işler üretilmeye başlanmıştır.

\section{Aquatinta (Tozlama) Tekniği}

Asit havuzunda iken erimeyen reçine tozlarının bir metal levha üzerine havalandırılarak veya dökülerek yüklenmesi ve ardından ısı yolu ile bu tozların eriyerek metale kaynaması sonucu levha üzerinde noktalar 


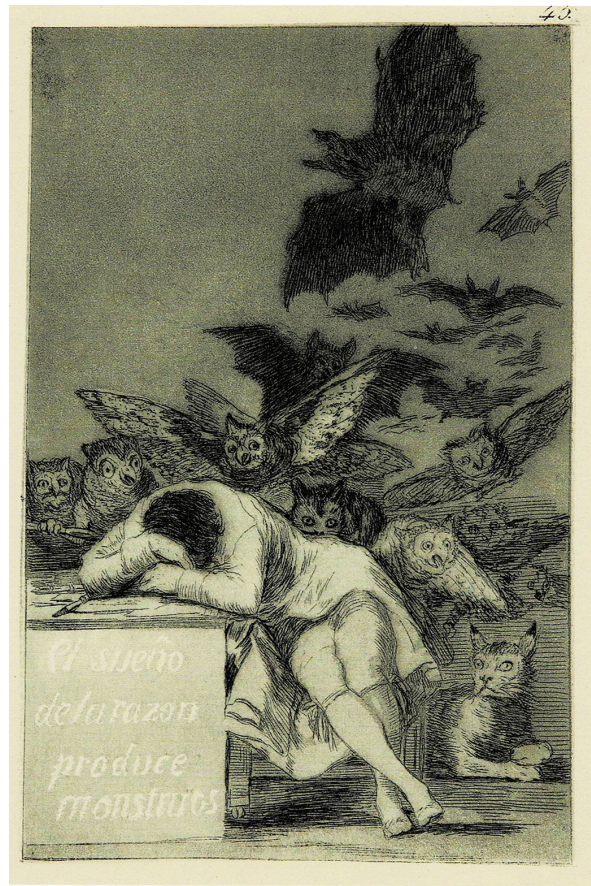

Görsel 2: Francisco Goya, Aklın Uykusu Canavarlar Doğurur, 1799, Aside Yedirme ve Aquatinta, $218 \times 252 \mathrm{~mm}$. oluşturulur. Bu levhanın asit havuzuna atılıp belli sürelerde bekletilmesi sonucu levha yüzeyinde noktalama tipinde delikler oluşur. Bu deliklere boya verilip baskı yolu ile kağıda yapılarak elde edilen baskı tipine Aquatinta denir. Aquatinta terimi ingilizcede aqua: su ve tinta: nokta kelimelerinden oluşur. Buradaki sudan anlaşılan şey çözeltilmiş asit sıvısı, noktadan anlaşılan ise yüzeyde oluşan nokta şeklindeki binlerce deliktir. "Aquatint etkisi, değişik ton alanları üretmek içindir. Bu bir plakada farlı derinliklerde çok ince bir dokuyu indirerek gerçekleşir. İndirme ne kadar derin olursa değer de o kadar koyu olur. Resim, kalıpta farlı tonların aşamalı yenmesiyle dolayısıyla oluşturulur.” (Grabowski - Fick, 2012, s.123)

Aquatinta tekniği tarihte ilk defa İspanyol ressam Francisco Goya tarafından resim sanatında kullanılmıştır. Aquatinta tekniği zaman içinde sanatçıların sıkça kullandığı bir resim tekniği olmuş ve bunun yanı sıra ekslibris sanatında da sıkça yararlanılan bir teknik olmuştur. Görsel 2'de Goya'nın elle yaptığı tozlama ile elde ettiği bir çalışması yer almaktadır.

Geleneksel olarak aquatinta tekniği asitli oyma ile çizgisel yapılandırılması oluşmuş levhalar üzerinde uygulanırdı. Günümüzde ise tek başına da uygulanmakta ve resmin her türlü değeri bu teknik ile elde edilebilmektedir. Tozlama yapılırken levha üzerinde toz tanelerinin sayısı ve boşluğun miktarı eşit olmalıdır. Ne çok ne az olmamalıdır. Tablo 1'deki çizimde levha üzerine serpilmiş reçine tozlarının seyrek, yoğun ve normal dağııım halleri görülmektedir.
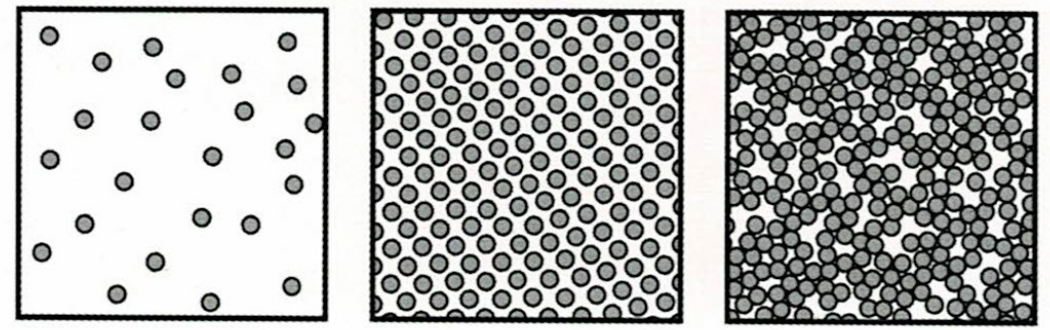

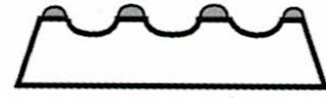

Seyrek dağılım

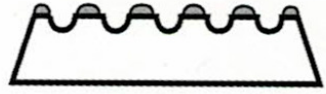

Normal dağılım

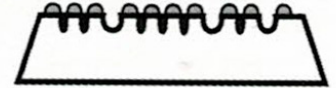

Yoğun dağılım
Tablo 1. Reçine Tozlarının Dağııım Tablosu.

Üzerine yapışmış reçine tozlu levha asit küvetinde farklı sürelerde bekletilebilir. Normal şartlarda 80 derecelik nitrik asit bir ölçek alınarak asit küvetinin içine dökülür. Üzerine de aynı ölçekle 12 defa normal su ilave edilir. Böylece tonlama yapılması istenen aquatinta tekniği için çözeltilmiş asit sıvısı elde edilmiş olur. Sanatçı levha üzerinde ilk olarak beyaz kalmasını istediği yerleri lak ile kapatır. Lak günümüzde şasi boyasının 
içine sentetik tiner katılarak elde edilebilmektedir. Kalıp, ilk aşamada 30 saniye asit küvetinde bekletilir ve bu süre bitince çıkartılır. İkinci aşamada levha üzerinde resme ait olan ve beyaza en yakın açık tonlu alanlar lak ile kapatılır ve bu kez 1 dakika asit sıvısının içine bırakılır. Sonra levha çıkartııır. Üçüncü aşamada 1.30 dakika, dördüncü aşamada 2.30, beşinci aşamada 4, altıncı aşamada 6.30 ve yedinci aşamada 10.30 dakika aynı işlem tekrarlanır. Yedinci ve son aşamada resimdeki en koyu olacak alanlar asitte en yüksek sürede bekletilerek asitleme işlemi tamamlanmış olur.

Asitleme aşamalarındaki süreler belirlenirken son bekletilen süre ve bir önceki süre toplanır ve bir sonraki süre elde edilir. Bu tip süre oluşumuna altın orantılı süre denir. Aşağıdaki tablo 2'de standart bir aquatinta asitleme için hazırlanmış bir çizelge görülmektedir. Görsel 3'de ise bu tabloya göre asitleme işlemi yapılmış bir test levhasından elde edilen baskı resim görülüyor.

\begin{tabular}{|l|l|l|l|}
\hline Aşamalar & Aşama Süresi & Aşamalar Toplamı & Genel Toplam \\
\hline 1. aşama & $30 \mathrm{sn}$ & 30 saniye & \\
\hline 2. aşama & $30+30 s n$ & 1 dakika & 1.30 dakika \\
\hline 3. aşama & $30 \mathrm{sn}+1 \mathrm{dk}$ & 1.30 dakika & 3 dakika \\
\hline 4. aşama & $1 \mathrm{dk}+1.30 \mathrm{dk}$ & 2.30 dakika & 5.30 dakika, \\
\hline 5. aşama & $1.30 \mathrm{dk}+2.30 \mathrm{dk}$ & 4 dakika & 9.30 dakika \\
\hline 6. aşama & $2.30 \mathrm{dk} .+4 \mathrm{dk}$ & 6.30 dakika & 16 dakika, \\
\hline 7. aşama & $4 \mathrm{dk} .+6.30 \mathrm{dk}$. & 10.30 dakika & 26.30 dakika, \\
\hline
\end{tabular}

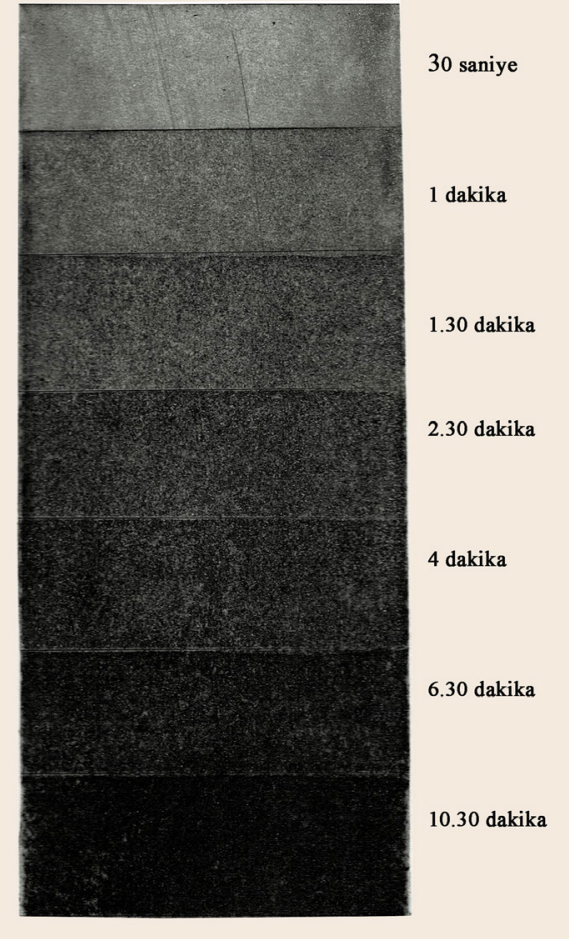

Görsel 3: Yedi aşamalı Aquatinta test levhası baskısı.

Tablo 2. Aquatinta tekniği için kullanılan standart 7 aşamalı asitleme süreleri tablosu.

“Aşama tablosunun en sağındaki genel toplam çizelgesi plaka üzerinde en son yapılan asitleme işinin toplam süresini verir. Normal değerlerdeki asit içinde 7. aşamanın sonundaki toplam süre olan 26.30 dakika yapılan çalışmalarda genelde yeterli bir sonuç olarak görülmektedir.” (Küçüköner, 2012, s.91-92) En son aşamadaki alanlar her aşamada asit küvetine girdiği için her defasında asit tarafından derinleşmektedir. Böylece siyah değerinde çok koyu tonlar elde edilebilmektedir.

Asitleme işi bittikten sonra levhanın yüzeyi önce tiner ile sonra da ispirto ile yıkanır. Artık elimizde üzerinde farklı seviyelerde binlerce deliği olan bir levha bulunmaktadır. Levhaya boya verilerek yüzeyde kalan kısımları temizlenir ve kalıp baskıya hazırlanır. Üzerine nemlendirilmiş kağıt yerleştirilerek presten geçirilir ve kalıptaki lekesel resim değerleri kağıt üzerine aktarılmış olur. Görsel 3'de yukardaki tabloya göre asitleme işlemi yapılan bir test levhasının baskısı görülmektedir. Sanatçı isterse asıl levhasını asitlemeden önce bir test levhası hazırlayabilir. Sudaki asit oranının yukarıdaki sıralamaya göre hangi ayarda tonlar vereceğini bu test levhasını çalışarak önceden görmek mümkündür. 


\section{Ekslibris Sanatında Aquatinta Tekniği Kullanılan Çalışmalardan Örnekler}

Yukarıda Ekslibris hakkında kısa bir tanıtım yaparak tarihi gelişim sürecini hatırlamaya çalıştık. Onun ardından Aquatinta tekniği ile ilgili tanımlama ve tarihi gelişim sürecinden kısaca bahsettik. Aquatinta tekniğinin temel özelliklerine değinerek yedi aşamalı bir çalışma için uyulması gereken bilgilere yer vermeye çalıştık. Bu bölümde ise aquatinta tekniği ile yapılan veya yapımında aquatinta tekniği kullanılan ekslibrislerden örneklere yer vermeye çalışacağız.

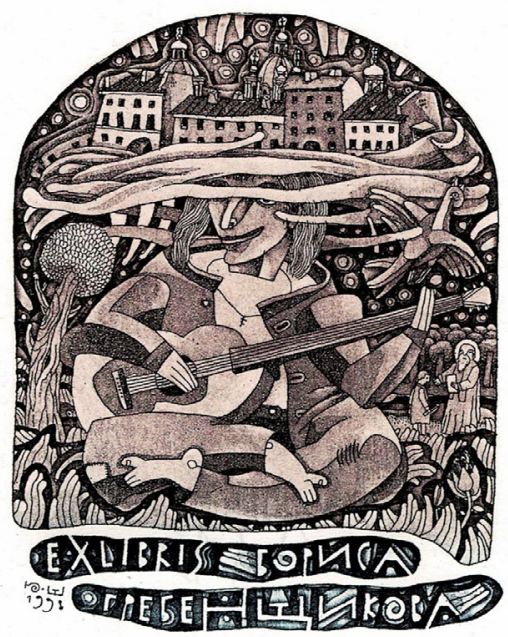

Görsel 4: Yury Shtapakov, 2005, $\mathrm{C}_{3}+\mathrm{C}_{5}, 115 \times 86 \mathrm{~mm}$.

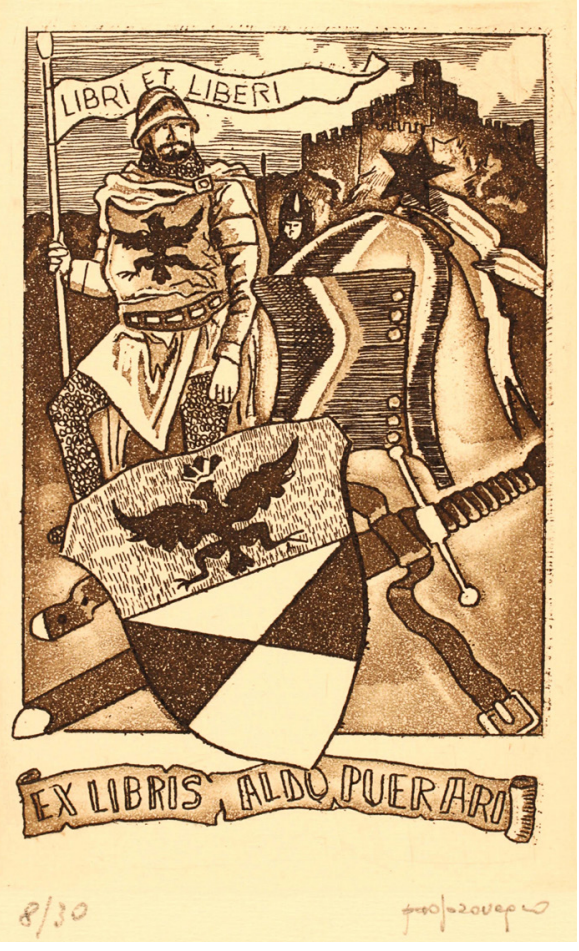

Görsel 5: Paolo Rovegno, Ex Libris Aldo Puerari, $\mathrm{C}_{3}+\mathrm{C}_{5}, 119 \times 78 \mathrm{~mm}$
Görsel 4'de Rus sanatçı Yury Shtapakov'a ait aquatinta tekniği ile yapılmış bir ekslibris çalışması görülmektedir. Çalışmanın ortasında elinde müzik aleti ile bağdaş kurmuş oturan bir figür resmin ana konusu olarak alanın çoğunu kaplamaktadır. Figürün kol ve bacaklarında ve elbisesinde aquatinta tekniği ile asitlenerek elde edilmiş beş farklı ton görmekteyiz. ilk aşamada beyaz yerler kapatılarak asidin etkisinden korunmuş, figürün elindeki gitarda, elbisesinde, ayaklarında ve gövdenin ışık alan yerlerinde beyaz ton yani ilk aşama asitleme kullanılmıştır.

Gitarda ve gövdede kütlesellik ve hacimselliği vermek için ikinci aşama olan beyaza yakın bir ton kullanılmıştır. Yine gitarın yan tahtasında ve gövdenin bazı yerlerinde koyu alanları verebilmek için orta tona yakın üçüncü bir ara ton tercih edilmiştir. Gitarın orta deliğinde, bacakların birleşimi olan alanda ve bacakların alt gölge alanında ise diğer tonlara kıyasla siyaha en yakın koyu ton kullanılmıştır.

Arkadaki evlerde de 5 ton kullanılmıştır. Sağdaki ve soldaki iki binanın ön cephesi beyazdır. Yatay uzun olanı 2. tonda, dikey ortada olanı ise 3 . tondadır. Çatılarda 4. ton değerler vardır. Pencere gibi içi karanlık alanlar ise 5. yani en koyu tondadır. Böylece resimde mekan hissi, perspektif ve kütlesellik görünümü temin edilmiştir. Sanatçı Ekslibris yazısında da tonlamalar yapmıştır. Bu tonlamalar harflerin biçimine benzemektedir. Bu çalışma aquatinta tekniğinin resme hakim olması açısından nadir bir örnektir.

Görsel 5'te italyan sanatçı Paolo Rovegno'nun yaptığı askeri türden bir ekslibris görülmektedir. Elindeki sancakta 'libri et liberi (bedava kitaplar)" yazısı tutmakta olan asker kalkanını yere indirmiş bir dinlenme anındadır. Askerin kalkanının alt eğimli bölümünde alanı çaprazlama bölerek dört parçaya ayıran çizgisel yapı karşılıklı alanların birbirleri ile eş tonda olması ve yan alanların ise zıt tonda olması şeklinde yapılandırılmıştır. iki tonlu bu yapıda en açık olan beyaz ton ile en koyuya yakın olan ton birbirleri ile kesişerek aşırı bir dinamizm oluşturmakta ve izleyicinin dikkatini çekmektedir. 
Kalkanın arkasında kalan ve ayakta dikilen figürün gövdesinde de iki ton vardır. Gövdenin ve elbisenin ışık alan yerleri beyaz, geride kalan yerler ise beyaza yakın bir ara tondadır. Kontör çizgileri ise "C3" yani çizgisel tarzda asitli oyma ile elde edilmiştir. Ressam az da olsa geleneğe bağlı kalarak siyah çizgisel alanları ve koyu tondaki alanları önce asitli oyma tekniği ile yapılandırmıştır. Sonra kalıba aquatinta tekniğini uygulamıştır. Askerin resme bakarken ki sol yanında ve geride kalan alan koyuya yakın ve tek bir tonda çalışıımıştır. Böylece figürde yer alan daha açık tonlar sayesinde figür bu arka alandan ayrılarak onun önüne geçebilmektedir.

Resimde sağ geri planda da aquatinta tekniği uygulanmıştır. Ancak buradaki açık koyu tonlama yöntemi figür ve etrafındaki uygulanan açıkkoyu tonlama yönteminden farklıdır. Bu farklılık iki şekilde elde edilmiştir. Sanatçı levhayı asit çözeltisinde bekletirken bazı yerlere müdahale etmiştir. En yakınındaki kontör çizgisine doğru git gide tonlama artmaktadır. Aslında bu açıktan koyuya tonlama dediğimiz klasik bir yöntemle yapılmıştır. Bazı yerlerde plaka ezilerek olduğundan açık alanlar elde edilmiştir. Oysaki figür ve kalkandaki açık koyu oluşumda geçişler eritilmemiştir. Daha belirgindirler. Bu belirginlik resmin bize göre sol alt alanındaki kemerin tek tonda koyu olması ve etrafının neredeyse tek tonda açık olmasında da görülmektedir.

Görsel 6'da Hasip Pektaş’a ait Sıtkı M. Erinç adına yapılmış bir ekslibris çalışması görmekteyiz. Çalışma dikine yapılanan ve dalları belli açılarla ayrılan ağaçlardan ve kuş yuvasından oluşmaktadır. Gövdelerin ve dalların dikey yönde uzuyor olmaları ile oluşan gerilimi dalların Ağaç dallarının diyagonal uzamları, ağaç dallarının dikey gerilimini rahatlatmaktadır. Sanatçı önce çizgisel yöntem ile ana hatları asitleme yolu ile belirlemiş, sonra aquatinta yöntemi ile resim geneline hakim olacak yeşil rengin ara tonlarını oluşturmuştur. Tonlama işleminde üç ton seçilmiştir. Resmin sol tarafından gelen ışıkla beraber ağaçların, dalların ve kutunun sola bakan yüzeyleri en açık olan tonda bırakılmıştır. Işığa en yakın olan ama yanda kalan ağaç gövdeleri ve dalların sağ tarafa bakan yerlerinde ve kutunun yukarı yüzeyinde ara ton uygulanmıştır. Kutunun sağ tarafa bakan yüzeyinde, önde duran ağaç gövdelerinin ve dalların arasında kalan alanlar ise koyu tonda verilmiştir. Böylece çok net bir derinlik algıSı oluşturulmuştur.

Resmin yukarısında ayrı plakalar ile resme dahil edilen yazı ekslibris yazısı da yeşilin orta tonu ile renklendirilerek resme dahil edilmiştir. En üstteki daire formundaki kırmızı renkli büst ise zıt renk olarak resme katkıda bulunmaktadır.

\section{(n)}

Görsel 6: Hasip Pektaş, Ekslibris Sıtkı M. Erinç, 1996, $\mathrm{C}_{3}+\mathrm{C}_{5}+\mathrm{P}_{1}, 120 \times 70 \mathrm{~mm}$. 


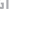

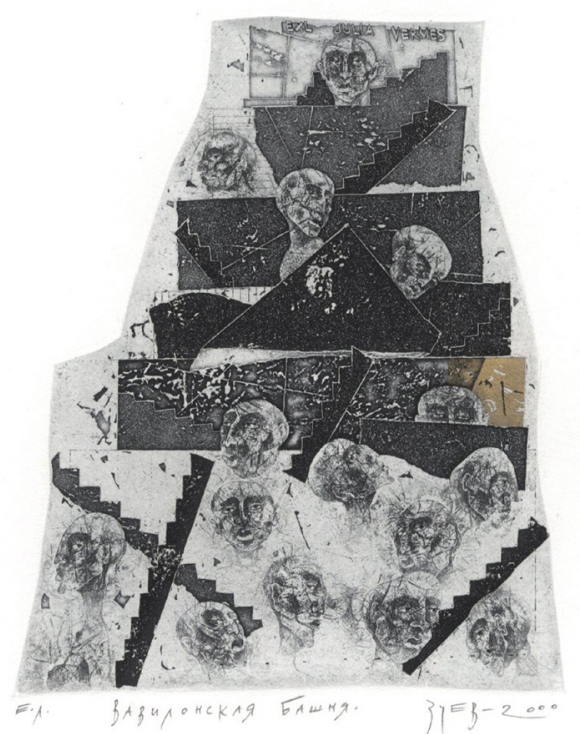

Görsel 7: Vladimir Zuev, Ekslibris Julia Vermes, Babil Kulesi, 2000, $\mathrm{C}_{3}+\mathrm{C}_{5}, 152 \times 123 \mathrm{~mm}$.

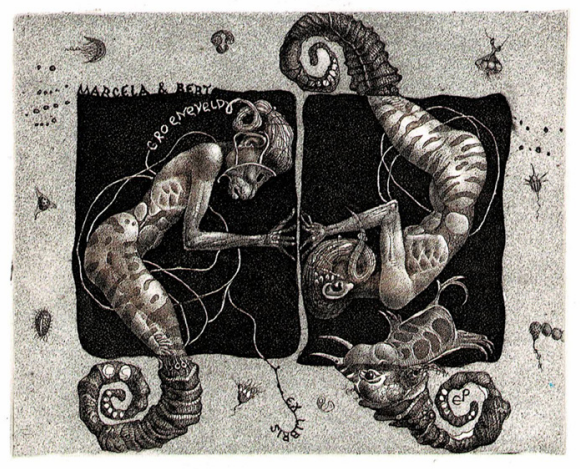

Görsel 8: Eduard Georgiev Penkov, $\mathrm{C}_{3}+\mathrm{C}_{5}, 103 \times 128 \mathrm{~mm}, 2004$
Görsel 7'de Vladimir Zuev'e ait bir ekslibris çalışması görüyoruz. Çalışma iki farklı tekniğin kullanılması ile oluşturulmuştur. Alt kısımda yer alan portrelerin oluşumunda asitli oyma tekniği kullanılmıştır. Resmin üst kısmında yer alan yatay merdiven biçimli geniş alanlardan oluşmuş kısım ise aquatinta tekniği ile yapılmıştır ve alttakine kıyasla resimde daha çok yer kaplar. Sanatçı resimde Babil Kulesi'ni çalışmıştır. resmin altına ad kulenin ismini yazmıştır. Babil Kulesinin yukarı doğru incelerek yükseldiğini görmekteyiz. Sanatçı merdivenleri ve merdivenlerin yer aldığı Kule katlarının duvarlarını birbirinden ayırt edebilmemiz için aquatinta tekniğinden yararlanmıştır.

En üstteki portrenin sol arkasında kalan merdiven biçimli duvar en koyu tonda yapılmıştır. Aynı portrenin altındaki duvar ise bu koyu duvara nazaran daha orta tonla çalışılmıştır. Bu duvarın üzerindeki merdiven ise en üsteki ilk duvar gibi en koyu tonla çalışılmıştır. Üstten aşağı ilerlerken üçüncü sırada yer alan duvar ise bir üsttekine göre biraz daha koyu, en üstteki koyu duvara nazaran ise biraz daha açık tonda çalışılmıştır. Üzerindeki merdiven ise en koyu tonda yapılmıştır. Üstten aşağı dördüncü sırada olan ve üçgen bir formda olan duvar ise yine en koyu tonda yapılmıştır. Bir alttaki duvar da orta tonlarda yapılmıştır. Bu duvar ve merdivenlerdeki ton farkları aquatinta tekniğinin bir sonucudur. Sanatçı aquatinta tekniğinin ton farkları oluşturması özelliğinden başarılı bir şekilde yararlanmıştır. Bu teknik sayesinde sanatçı hem yukarı-aşağı, hem arka-ön, hem de açık-orta-koyu alanları oluşturmuştur.

Görsel 8'de Belçikalı sanatçı Eduard Georgiev Penkov’un yaptığı bir ekslibris görmekteyiz. Resmin tamamına " $\mathrm{C}_{5}$ " aquatinta tekniği hakim olmakla beraber az sayıda da "C5" asitli oyma mevcuttur. Resim oluşturulurken kalıbın tüm yüzeyine tozlama yapılmıştır. Resim temel olarak üç plandan oluşmaktadır. Arka plan, orta plan ve ön plan. Kalıp asit işleminde iken arka plan beyaza yakın bir aşamada bırakıımış, levhanın bu alanları lak ile kapatılmıştır. Sanatçı bunun zıttı olarak orta planda yer alan ve en öndeki iki figürü öne çıkarma işlevi gören koyu alanı ise son aşamaya kadar asitleme işlemine tabi tutmuştur. En gerideki açık alanın üzerine gelen bu koyu alan resimde bir iç resim alanı üretmektedir. Ayrıca koyu oluşu ile de arkadan ayrılarak öne doğru çıkmaktadır.

Ön plandaki iki figür ise açık, orta ve koyu tonlarla yapılmıştır. Resmin orta planında yer alan en koyu tondaki alanın koyuluk derecesi bu figürlerde yoktur. Figürlerdeki en koyu aquatinta tonu neredeyse orta alandaki en koyu tonun yarısı değerinde kalmaktadır. Sanatçı saçlarda ve birkaç yerde asitli oyma sayesinde daha koyu tonda çizgiler ilave etmiştir. Ancak figürler genel olarak en açık ton ile orta ton arasındaki diğer ton geçişleri ile resmedilmişlerdir. 

.

Görsel g'da sanatçı Nesli Sisli tarafından asitli oyma ve aquatinta teknikleri ile yapılmış bir ekslibris görmekteyiz. Sanatçı kullandığı levhayı, resme yerleştirdiği figürlerin dış biçimlerine uygun olarak keserek farklı bir kalıp elde etmiş. Figürlerin ana çizgilerini elde etmek için ve arkadaki taş duvarın çizgisel ve koyu alanlarını oluşturabilmek için " $\mathrm{C}_{3}$ ” asitli oyma tekniğini kullanmıştır. Figürlerin tamamındaki tonlamaları elde edebilmek içinse " $\mathrm{C}_{5}$ " aquatinta tekniğini kullanmıştır.

Sanatçı önce kalıba çizgisel yapılandırma ile hem figürleri hem de duvarın taşlarını yapmıştır. Sonra figürlerin ve duvarın ton değerleri ayırt edilebilsin diye, tozlama işlemi sırasında levha üzerinde iki farklı büyüklükte tanecikler içeren tozlama işlemi kullanmıştır. Önce tüm kalıba reçine dolabında ince tozu yüklemiş, sonra duvarın bazı alanlarına kalın toz tanecikleri serpmiştir.

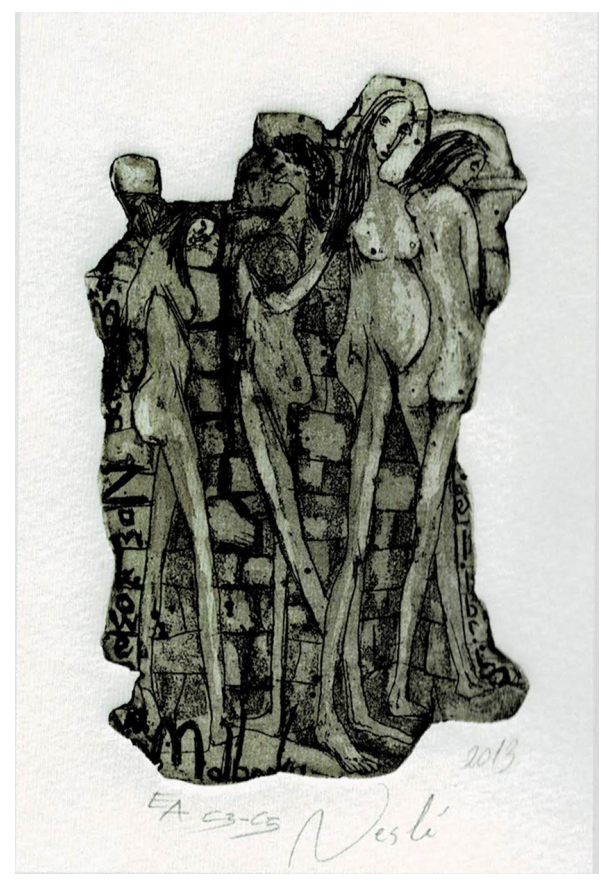

Görsel 9: Nesli Sisli, Ex libris Muzeum w Malborku, 2013, $\mathrm{C}_{3}+\mathrm{C}_{5}, 10.5 \times 6.5 \mathrm{~cm}$.

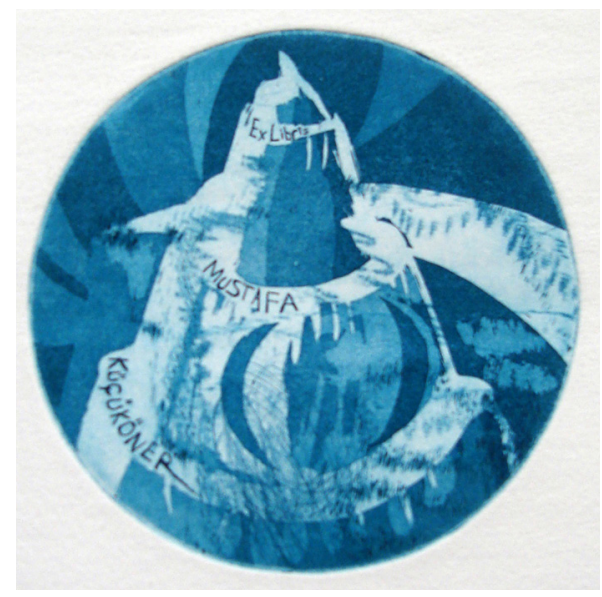

Görsel 10: Mustafa Küçüköner, Ekslibris Mustafa Küçüköner, 2010, C3,C5, Çap: 120 mm.
Eritme ve asitleme işleminden sonra ince tozlar kalıp üzerindeki ince ve sıkı, kalın tozlar ise seyrek ve kalın noktalar oluşturmuştur.

Duvardaki kalın ve ince tozlanmanın asitte bekleme süresi aynı olmuş ve orta tona yakın bir açık değerde asitleme işlemi tamamlanmıştır. Figürlerde ince taneli tozlar yer almaktadır. Bu figürler ise açık ve koyu iki farklı tonlama ile yapılmıştır. Açık tonlama yapılan alanlardaki ton değeri duvardaki ton değeri ile aynı tutulmuştur. Bu sayede figürler ile duvar arasında yakınlık sağlanmıştır. Açık tonlama sayesinde de figürlerdeki ışıklı alanlar ortaya çıkartılmıştır. Ekslibris yazısı ve ait olduğu kişinin adının yazısı ise koyu olması için sanatçı tarafından kalıbın çizgisel yapım aşamasında çalışı ımıştır.

Görsel 10'da sanatçı Mustafa Küçüköner tarafından kendi adına yapılmış daire formunda bir ekslibris görülmektedir. Ortadaki Babil Kulesi formu sanatçının çoğu çalışmasında kullandığı bir temadır. Resimde kalıbın her yerinde aquatinta tekniği kullanılmış ve Kule ile arka plan ton farkları sayesinde ayrılmıştır. Kulenin sol yamaçları resimdeki en açık tonu oluşturmaktadır. Kulenin ortalarına yaklaştıkça açık tona yakın olan orta tonlar devreye girmekte ve Kulenin spiral yapısını ortaya çıkarmaktadır. Kulenin solundaki beyaz tonlamanın zıttı olarak sol arkada kalan alan orta ve koyu tonlama ile resmedilmiştir. Böylece Kule ve arka plan birbirinden ayrılmıştır.

Kulenin sağ tarafında ise koyu tonlama mevcuttur. Kulenin buradaki kontör çizgisi ise en açık tondadır ve çizgisel bir yapıdadır. Bu açık tonlu çizgisel yapı sadece kontörü çevrelemekle kalmaz, aynı zamanda Kuleye spiral şeklinde dönerek tırmanan patikamsı yolun üzerine doğru da uzar. Böylece beyaz alanlar, resimde en açık tonu oluşturarak hem Kulenin sağ taraftaki arka plandan ayrılmasını sağlamakta, hem de Kulenin ışıkla aydınlanan yerlerini oluşturmaktadır. 


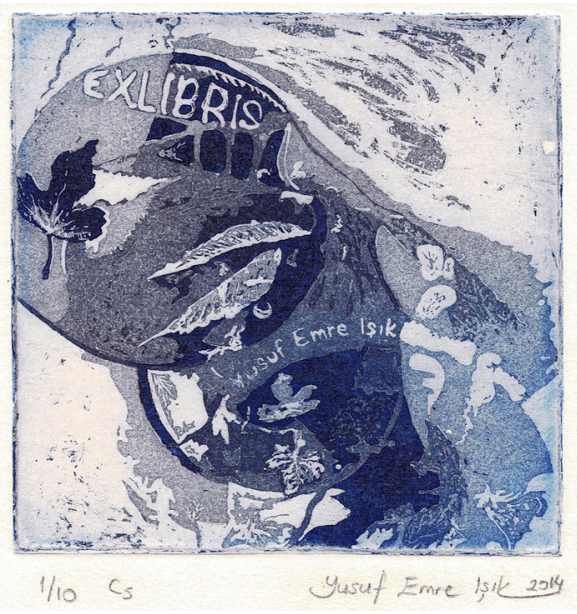

Görsel 11: Yusuf Emre Işık, Ekslibris Yusuf Emre Işık, 2014, C5, 125X128 mm.
Resimdeki ekslibris yazısı ise asitli oyma tekniği ile ve dar çizgisel bir şekilde çalışılmıştır. Yazı koyu tondadır ve resimdeki en açık ton olan alanlara yerleştirilerek ön palan çıkması sağlanmıştır.

Görsel 11'de Yusuf Emre Işık tarafından "C5" Aquatinta tekniği ile kendi adına yapılmış bir ekslibris çalışması görmekteyiz. Bu çalışmada sadece aquatinta tekniği kullanılmış, resim ve yazı açıktan koyuya tüm yüzeyde yer alan aquatinta tonlamaları ile ortaya çıkartılmıştır. Sanatçı bu kalıbı 7 aşamada asitlemiştir. Yukarıda tablo 2'de yer alan asitleme aşama ve sürelerini kullanmıştır.

Sanatçı ilk olarak kalıpta resme ait beyaz alanları lak ile kapatmış ve 30 saniye asitli suda bekletmiştir. Sonra kalıbını çıkartarak beyaza en yakın olan ikinci tonu asitli suya bırakmış ve 1 dakika bekletmiştir. Sıra ile diğer aşamaları da yaptıktan sonra kalıbını temizlemiş ve baskı işlemine geçmiştir. Farklı sürelerde asitli suda kaldığı için bu ton farklıı̆̆ı kalıbın üzerinde boya varken de belli olmaktadır.

Resimde açık tonlardan oluşan bir arka plan ve iki dairemsi yapının iç içe geçtiği hareketli bir ön plan vardır. Arka plan ilk iki aşamadaki beyaz ve beyaz yakın en açık ton ile yapılandırıldığı için sakin bir şekilde ve geride durmaktadır. Dairelerin kesiştiği ön planda en açık tondan en koyu tona kadar yedi farklı ton mevcuttur. Bazı yerlerinde en açık ton ile en koyu ton yan yanadır ve bu ilişki aşırı derecede kontrastlık oluşturmaktadır. Bu kontrastlık ise izleyicinin dikkatini bu öndeki alanlara çekmektedir. En koyu tonların da arka planda değil de sadece ön planda yer alması da resme bakışı bu alana çekmeye sebep olmaktadır.

\section{Sonuç}

"Ekslibris Sanatında Aquatinta Tekniği ile Tonlama” başlığı adı altında ele aldığımız bu çalışmada kısaca ekslibris sanatından bahsedilmiş, sonra aquatinta tekniği tanıtılmaya çalışıımış, aquatinta tekniği ile yapıımış olan ekslibris resimlerden örnekler verilmiştir.

Aquatinta tekniği ile resimde tonlama yapılabildiği, örnek resimlerden yola çıkılarak anlatılmaya çalışıımıştır. Bu teknik ile çalışırken sanatçı sulu boya resim ya da yağlı boya resimdeki gibi efektleri daha kolay elde edebilmektedir.

Bu çalışmadan yararlanarak sanatçıların ekslibris çalışması yaparken aquatinta tekniğinden daha fazla faydalanmaları beklenmektedir. Ayrıca bu çalışma, sonraki çalışmalarımızda yer alacak olan iki kalıplı aquatinta tekniği ile renkli ekslibris yapma işi için de bir ön çalışma olarak literatürde yerine almaktadır. 


\section{Kaynakça}

Grabowski, Beth., Fick, Bill. (2012). Baskıresim, Kapsamlı Materyaller ve Teknikler Rehberi, (Simber Atay Eskier, Arif Ziya Tunç, Çev), Karakalem Kitabevi Yayınları, İzmir.

Kahramankaptan, Şefik. (1997). Kitaba Görsel Katkı: Ekslibris, Gösteri Sanat Dergisi, Sayı: 154, S: 67

Küçüköner, Hava. (2012). Gravür Sanatı Tarihi ve Modern Uygulamalar. (Yayınlanmamış Yüksek Lisans Tezi). Atatürk Üniversitesi, Sosyal Bilimler Enstitüsü. Erzurum.

Pektaş, Hasip. (2017). Ekslibris, i̇stanbul Ekslibris Derneği Yayını, i̇stanbul.

\section{Diğer Kaynaklar}

Gölönü, Gündüz. (1979). Kazı Resim. İstanbul Devlet Güzel Sanatlar Akademisi Yayını, No:68.

Keenan, James P. (2003). The Art of the Bookplate. Barnes \& Noble Books. New York.

Okur, Gökhan (1998). Exlibris ve iletişim. H.Ü. Sosyal Bilimler Enstitüsü Grafik Anasanat Dalı. Yüksek Lisans Tezi. Ankara

Rona, Zeynep (2003). “Exlibris ve Özgün Baskıresim Sergisi”. Türkiye Sanat Yıllığı. İstanbul.

Temel, Sema Ilgaz (1997). "Kitabın İçindeki Mülkiyet Sembolü Exlibris”. Sanatsal Mozaik Dergisi, ìstanbul.

\section{Kataloglar}

Erinç, Sıtkı M. (2007). Hasip Pektaş Ekslibris Kataloğu, Ankara.

Goya Zamanının Tanığı Gravürler ve Resimler, (2012), Pera Müzesi Sergi Kataloğu, istanbul.

I. Uluslararası Exlibris Yarışması Sergisi Kataloğu, (2003), Hacettepe Üniversitesi, Ankara Ekslibris Derneği, Ankara

II. Uluslararası Exlibris Yarışması Sergisi Kataloğu, (2007), Hacettepe Üniversitesi, Ankara Ekslibris Derneği, Ankara 


\section{Tablo Kaynakları}

Tablo 1. Reçine Tozlarının Dağılım Tablosu. Kaymak: Grabowski, Beth. Fick, Bill. (2012). Baskıresim, Kapsamlı Materyaller ve Teknikler Rehberi, Çev: Simber Atay Eskier, Arif Ziya Tunç, Karakalem Kitabevi Yayınları, İzmir, s.124.

Tablo 2. Aquatinta tekniği için kullanılan standart 7 aşamalı asitleme süreleri tablosu. Kaynak: Küçüköner, Hava. (2012). Gravür Sanatı Tarihi ve Modern Uygulamalar. (Yayınlanmamış Yüksek Lisans Tezi). Atatürk Üniversitesi, Sosyal Bilimler Enstitüsü. Erzurum, s.91.

\section{Resim Kaynakları}

Resim 1. Albrecht Dürer, Willibald Pirckheimer için ekslibris. Kaynak: Pektaş, Hasip. (2017). Ekslibris, İstanbul Ekslibris Derneği Yayını, İstanbul, S.16

Resim 2. Francisco Goya, Aklın Uykusu Canavarlar Doğurur, Kaynak: Goya Zamanının Tanığı Gravürler ve Resimler, (2012), Pera Müzesi Sergi Kataloğu, istanbul, s.174.

Resim 3. Yedi aşamalı Aquatinta test levhası baskısı. Kaynak: Mustafa Küçüköner Arşivi

Resim 4. Yury Shtapakov, Kaynak: II. Uluslararası Exlibris Yarışması Sergisi Kataloğu. (2007), Ankara, s.58.

Resim 5. Paolo Rovegno, Ex Libris Aldo Puerari, Kaynak: http://art-exlibris. net/exlibris/25838

Resim 6. Hasip Pektaş, Ekslibris Sıtkı M. Erinç, Kaynak: Pektaş, Hasip. (2017). Ekslibris, İstanbul Ekslibris Derneği Yayını, İstanbul, s:120.

Resim 7. Vladimir Zuev, Ekslibris Julia Vermes, Babil Kulesi, Kaynak: http:// www.vladimirzuev.com/etchings.html

Resim 8. Eduard Georgiev Penkov, II. Uluslararası Exlibris Yarışması Sergisi Kataloğu, (2007), Hacettepe Üniversitesi, Ankara Ekslibris Derneği, Ankara, s: 100 .

Resim 9. Nesli Sisli, Ex libris Muzeum w Malborku, Kaynak: 24th International Biennial Exhibition of Modern Exlibris Malbork Katoloğu, (2013), Malbork, Polonya, S:206 
Resim 10. Mustafa Küçüköner, Ekslibris Mustafa Küçüköner. Kaynak: Mustafa Küçüköner Ekslibris Koleksiyonu.

Resim 11. Yusuf Emre Işık, Ekslibris Yusuf Emre Işık. Kaynak: Mustafa Küçüköner Ekslibris Koleksiyonu.

\section{Prof. Mustafa Küçüköner}

Necmettin Erbakan Üniversitesi

Güzel Sanatlar Fakültesi

Resim Bölümü- 05303122925

mustkoner@hotmail.com 